Proc. Estonian Acad. Sci. Eng., 2001, 7, 2, 141-156

\title{
MODELLING OF COASTAL CIRCULATION AND OIL DRIFT AT POSSIBLE DEEP HARBOUR SITES, NORTH-WESTERN SAAREMAA ISLAND
}

\begin{abstract}
Jüri ELKEN
Estonian Marine Institute, Paldiski mnt. 1, 10317 Tallinn, Estonia; elken@phys.sea.ee

Received 21 March 2001

Abstract. In a short-term project related to the environmental impact assessment of the possible locations of a deep harbour in the north-western Saaremaa Island, Estonia, the oil drift probability was investigated by applying Lagrangian particle tracking on the currents from the coastal circulation model. In a four-step nested three-dimensional circulation model, the coarsest grid covered the whole Baltic Sea area with a 4 mi grid step. One-way nesting with the use of sponge layers refined each subsequent grid by a factor of four, reaching on the finest grid the 1/16 mi grid step. Due to unstratified conditions in the bays and to the need for computational efficiency, the Bryan-Cox-Killworth model was recoded for barotropic conditions and implicit timestepping. Calibration run, using forcing data from the local wind measurements that were near the coast corrected by fetch dependent wind speed reduction, gave satisfactory agreement with direct current observations. Using the calibrated model, time series of the current patterns were calculated for a 32 week period in 1991 using the gridded wind fields over the Baltic Sea. Further, the oil drift probability was calculated by recollecting on the grid counter the number of particles reaching a specific grid point after $24 \mathrm{~h}$ of drift. If the harbour will be located near the Vilsandi National Park, then probability of oil spill drift to the coasts of the protected territory is low. However, the risk of oil contamination of the nearby wintering areas of globally endangered Steller's Eider remains. The Suuriku-Kuriku site was found to be the most suitable harbour location with the least consequences of oil spill drift.
\end{abstract}

Key words: coastal circulation, circulation model, oil spill, environmental impact assessment, Baltic Sea.

\section{INTRODUCTION}

Within the planning of a new deep harbour in the north-western Saaremaa Island, preliminary environmental impact assessment (EIA) of the selected sites $\left[{ }^{1}\right]$ has pointed out the risk of oil pollution from the harbour and navigating ships as one of the greatest hazards for the environment. Besides the general 
well-known negative effects of oil pollution that may appear, for example, on seabirds and marine mammals even eight years after an accident $\left[{ }^{2,3}\right]$, small bays of the north-western Saaremaa are especially sensitive. Considerable part of globally endangered Steller's Eider Polysticta stelleri world population is wintering in Saaremaa $\left[{ }^{4}\right]$. The small islets near the coast are also sanctuaries of seals that are protected species in the Baltic Sea area.

Many countries have established operational model-based oil drift forecast systems to facilitate combating oil pollution $\left[{ }^{5-7}\right]$. However, these systems are not accurate enough and they are being continuously updated $\left[^{8}\right]$. In the Baltic Sea area, the countries are implementing oil drift forecast systems according to the HELCOM recommendation $\left[{ }^{9}\right]$. The oil drift models are also used, if necessary, in support of EIA $\left[{ }^{10}\right]$.

Following the EIA conducted in $1999\left[^{1}\right]$, Estonian Ministry of Environment ordered a hydrodynamical and geological study of three possible harbour locations on the Tagamõisa Peninsula. They are Undva in the Uudepanga Bay and two sites in the Tagalaht Bay: Suuriku-Kuriku at the entrance of the bay and Vaigu on its western coast (see inside back cover of this issue). This 3 month project was considered as complementary to the EIA. With respect to environmentally important oil risk, the investigation had to quantify which of the harbour sites will less probably pollute environmentally sensitive areas if the oil spill would occur near the harbour.

This paper gives the estimates of drift probability of potential oil spills located near the possible harbour sites. Prior to oil drift modelling, the first step is to implement a relatively simple and computationally efficient circulation model that is capable of simulating the observed features of the currents with a reasonable accuracy. The model is used for calculating time series of current patterns that are long enough to encounter the long-term statistics of the wind speed and direction. Estimation of the oil drift probability is done by Lagrangian particle tracking by releasing the particles at different time moments into precomputed current patterns and recollecting final drift locations after $24 \mathrm{~h}$ of drift. The paper also considers how much the overall circulation of the small bays and local flows will be altered when the harbour construction is finished. Finally, suitability of different harbour sites is evaluated.

\section{IMPLEMENTATION OF THE CIRCULATION MODEL}

Both of the bays of interest have rather small dimensions as shown on the model grid maps in Fig. $1^{*}$. The grid parameters are given in Table 1. The Tagalaht Bay has a length of about $10 \mathrm{~km}$ and is widening from $4.2 \mathrm{~km}$ at the centrally located Vaigu towards the entrance area reaching $7.2 \mathrm{~km}$ at SuurikuKuriku. The Uudepanga Bay has a semicircular shape with a diameter about $3.5 \mathrm{~km}$. Therefore the grid step of the hydrodynamic circulation model should be

* Asterisks mark the coloured figures on unnumbered inserts. 
less than $200 \mathrm{~m}$. The maximum depth in the Uudepanga Bay amounts to $22 \mathrm{~m}$. The Tagalaht Bay has near Vaigu maximum depth of $20 \mathrm{~m}$ that increases to $30 \mathrm{~m}$ in the entrance area. Taking into account that outside the bays the maximum depth amounts to $50 \mathrm{~m}$, the maximum phase speed for long gravity waves is $22 \mathrm{~m} / \mathrm{s}$. Subsequently, the Courant-Friedrich-Levy stability criterion constrains the maximum time step for the free-surface mode to less than $10 \mathrm{~s}$. The BryanCox-Killworth model, that has been used in Estonia for the Baltic-wide circulation modelling $\left[{ }^{11}\right]$, becomes with such small grid steps computationally impractical, even if multi-step nesting is used.

Table 1. Parameters of nested grids

\begin{tabular}{lccccc}
\hline & Grid1 & Grid2 & Grid3 & Grid4 \\
\hline$x_{\min }$ & $12.0000 \mathrm{E}$ & $20.8000 \mathrm{E}$ & $21.5000 \mathrm{E}$ & $21.7500 \mathrm{E}$ \\
$x_{\max }$ & $30.0000 \mathrm{E}$ & $24.8000 \mathrm{E}$ & $22.6000 \mathrm{E}$ & $22.1750 \mathrm{E}$ \\
$y_{\min }$ & $54.0000 \mathrm{~N}$ & $57.0000 \mathrm{~N}$ & $58.3000 \mathrm{~N}$ & $58.4125 \mathrm{~N}$ \\
$y_{\max }$ & $65.8000 \mathrm{~N}$ & $59.6000 \mathrm{~N}$ & $58.9250 \mathrm{~N}$ & $58.6000 \mathrm{~N}$ \\
Grid points $x$ & 136 & 121 & 133 & 205 \\
Grid points $y$ & 178 & 157 & 151 & 181 \\
Grid step $\Delta x, \mathrm{~m}$ & 7434.23 & 1947.36 & 482.59 & 121.00 \\
Grid step $\Delta y, \mathrm{~m}$ & 7411.84 & 1852.96 & 463.24 & 115.81 \\
Maximum depth $H_{\max }, \mathrm{m}$ & 200 & 200 & 80 & 55 \\
$3 \mathrm{D}$ mode time step $\Delta t_{u}, \mathrm{~s}$ & 600 & 600 & 600 & 600 \\
$2 \mathrm{D}$ mode time step $\Delta t_{\xi}, \mathrm{s}$ & 150 & 30 & 15 & 5 \\
$\Delta z_{m}(1-10), \mathrm{m}$ & 2 & & & \\
$\Delta z_{m}(11-20), \mathrm{m}$ & 10 & 10 & 2 & 2 \\
$\Delta z_{m}(21), \mathrm{m}$ & 10 & 10 & 5 & 5 \\
$\Delta z_{m}(22), \mathrm{m}$ & 10 & 10 & 5 & 5 \\
$\Delta z_{m}(23), \mathrm{m}$ & 10 & 10 & 10 & 5 \\
$\Delta z_{m}(24), \mathrm{m}$ & 20 & 20 & 10 & 5 \\
$\Delta z_{m}(25), \mathrm{m}$ & 30 & 30 & 20 & 5
\end{tabular}

Further arguments for the model implementation come from the hydrodynamic observations $\left[{ }^{12}\right]$ performed during the project. There were no measurement results available prior to the project. In September-October 2000, both of the bays were nearly unstratified in terms of density. Moreover, the horizontal density gradients were in general also small. Therefore strong baroclinic features like fronts and eddies, that are important for oil drift in stratified regions $\left[{ }^{13}\right]$, did not appear and baroclinicity could be considered of minor importance during most of the year, except maybe for the few months summer period with a shallow thermocline. At the same time, the currents in the Tagalaht Bay had a two-layer structure where a compensation flow, opposing the surface drift, took place below $15 \mathrm{~m}$ depth $\left[{ }^{12}\right]$. The current time series recorded at the autonomous buoy stations were found to be generally dependent on local wind forcing measured by the automatic recording weather station at the Undva Cape. However, the 
recorded currents were not fully coherent with the local wind forcing. This means that it was not possible to use for the oil drift estimates the precomputed stationary current patterns corresponding to different wind conditions.

The hydrodynamic model of the bays of interest has to be nonstationary. For considering the remote forcing of currents by transient Kelvin waves excited in other regions of the Baltic Sea, the local model has to be linked to the Balticwide model. In order to resolve the compensation flow in the Tagalaht Bay, the model has to be three-dimensional (3D). Finally, baroclinic part can be excluded from the model because of observed non-baroclinic regime. The latter argument allows to increase computational efficiency and avoid baroclinic initialization problems for the specific investigation period when the Baltic-wide temperature and salinity data are not yet available.

The original Bryan-Cox-Killworth free surface model $\left[{ }^{14}\right]$ was fully recoded to meet the needs for computational efficiency in coastal regions. Horizontal and vertical grid structure corresponding to the Arakawa B-grid is retained in order to allow easier coupling with the large-scale original baroclinic model in the future. As for the original model, the solution is decomposed into the depth-integrated two-dimensional (2D) and the depth-dependent 3D mode that have different time steps.

Assume that for time step $n$, presenting the model time $t_{n}=n \Delta t_{u}$, the horizontal velocity components $\mathbf{u}^{n}=\left(u^{n}, v^{n}, 0\right)$ are already computed. With known values of the water level $\xi^{n}$, turbulent viscosity coefficients $\mu^{n}, v^{n}$, and vertical velocity $w^{n}$ (derived from the continuity equation), the horizontal momentum equations are written with implicit time differences as

$$
\frac{\tilde{\mathbf{u}}^{n+1}-\mathbf{u}^{n}}{\Delta t_{u}}+\Lambda_{h}^{n} \widetilde{\mathbf{u}}^{n+1}+w^{n} \frac{\partial \widetilde{\mathbf{u}}^{n+1}}{\partial z}-\mathbf{f} \times \tilde{\mathbf{u}}^{n+1}=-g \operatorname{grad}_{h} \xi^{n}+\mathbf{M}_{h}^{n} \widetilde{\mathbf{u}}^{n+1}+\frac{\partial}{\partial z} v^{n} \frac{\partial \tilde{\mathbf{u}}^{n+1}}{\partial z},
$$

where horizontal advection operator is defined as

$$
\Lambda_{h}^{n}=u^{n} \frac{\partial}{\partial x}+v^{n} \frac{\partial}{\partial y}
$$

$\mathbf{f}=(0,0, f)$ is Coriolis parameter, $g$ is gravity acceleration and horizontal turbulent friction operator is given as

$$
M_{h}^{n}=\frac{\partial}{\partial x} \mu^{n} \frac{\partial}{\partial x}+\frac{\partial}{\partial y} \mu^{n} \frac{\partial}{\partial y} .
$$

Finite difference equivalent of Eq. (1) for finding an intermediate value of $\widetilde{\mathbf{u}}^{n+1}$ is solved in three space directions by the splitting method using three-diagonal matrix elimination. Vertical part of Eq. (1), excluding $\Lambda_{h}^{n}$ and $\mathbf{M}_{h}^{n}$, presents the problem of nonsteady Ekman spiral that is solved with boundary conditions 
(a)

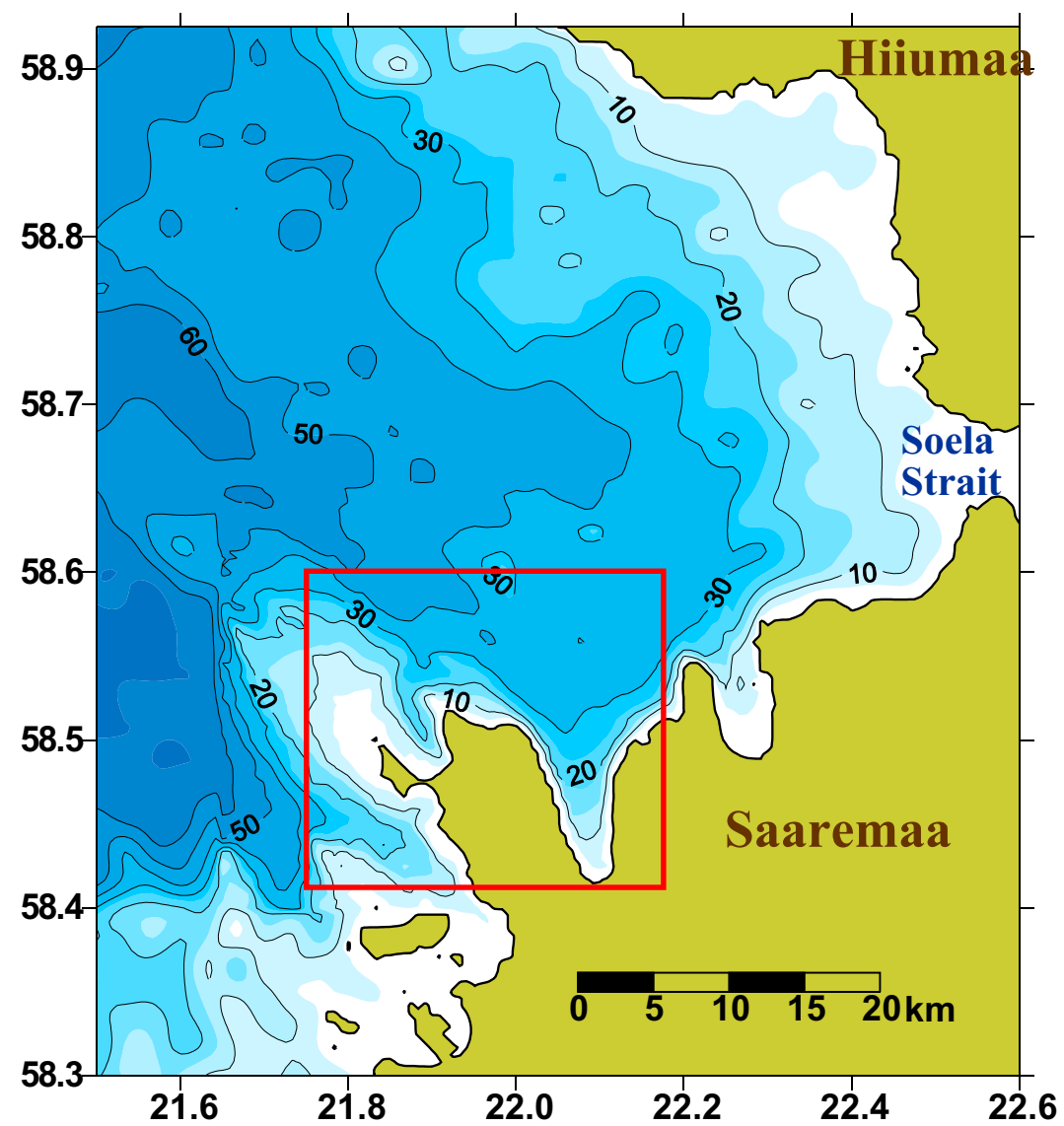

(b)

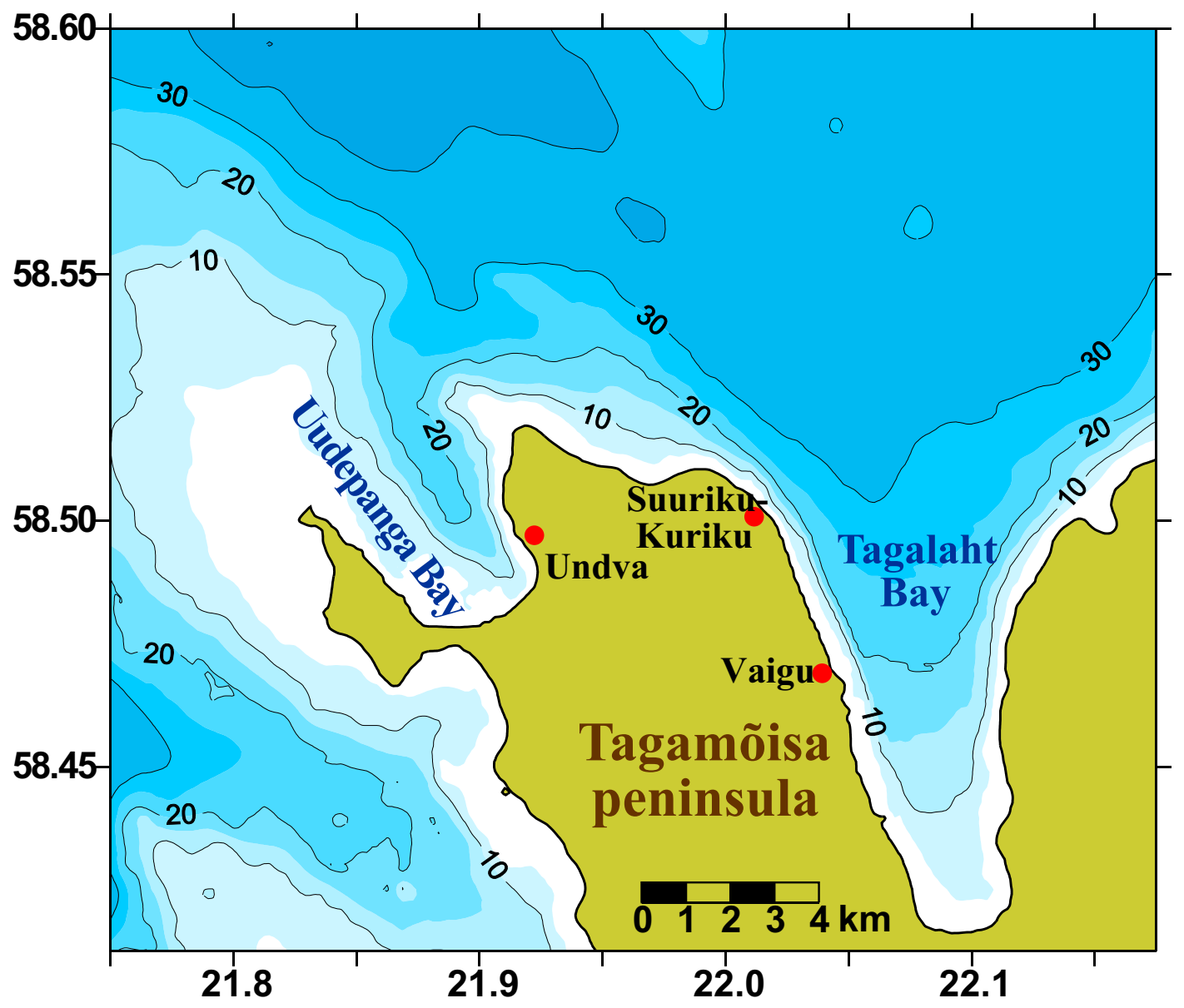

Fig. 1. Topography of the two finest grids of the circulation model. 
(a)

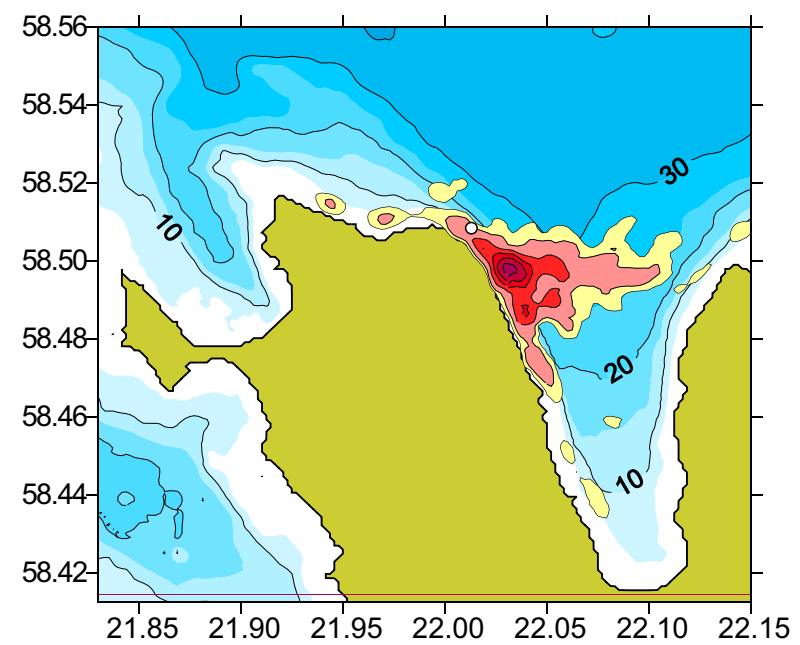

(b)

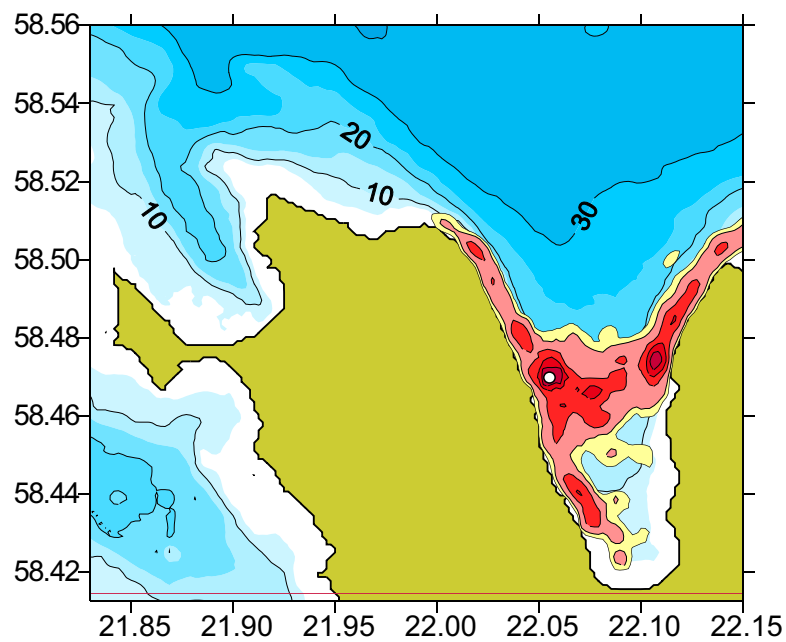

(c)

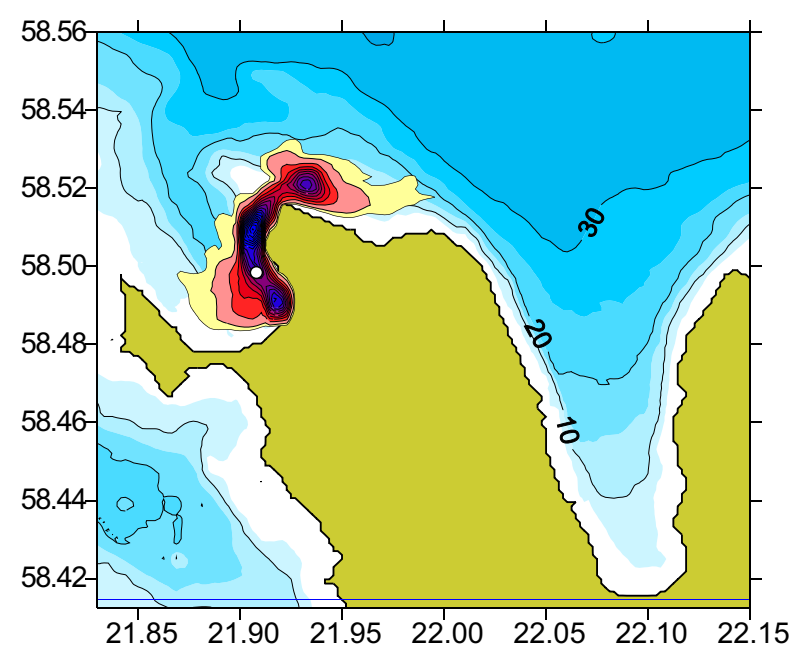

Fig. 4. Oil drift probability of the potential oil spill (shown by a white dot) occuring near Suuriku-Kuriku (a), Vaigu (b), and Undva (c).The probability of finding the oil segments increases from yellow (low) to red (medium) and dark violet (high). 


$$
\left.\rho v \frac{\partial \tilde{\mathbf{u}}^{n+1}}{\partial z}\right|_{z=0}=\boldsymbol{\tau},\left.\quad \rho v \frac{\partial \tilde{\mathbf{u}}^{n+1}}{\partial z}\right|_{z=-H}=\boldsymbol{\tau}_{b}=\rho c_{d} \mathbf{u}^{n}\left|\mathbf{u}^{n}\right|,
$$

where $\tau$ is the wind stress, $\rho$ is the water density, and $c_{d}$ is the bottom drag coefficient. On the next splitting steps advection-diffusion equations for velocity components are solved subsequently in $x$ and $y$ directions. Within the desired large time step, compared to the stability criterion of explicit numerical scheme, downstream advection formulation was found more suitable to suppress the nonlinear instability than the centered differences formulation.

In the time interval from $n \Delta t_{u}$ to $(n+1) \Delta t_{u}$, water level is determined from the $2 \mathrm{D}$ shallow water equations

$$
\begin{gathered}
\frac{\mathbf{U}^{k+1}-\mathbf{U}^{k}}{\Delta t_{\xi}}-\mathbf{f} \times \mathbf{U}^{k}=-g H \operatorname{grad}_{h} \xi^{k}+\mathbf{F}^{n, n+1}, \\
\frac{\xi^{k+1}-\xi^{k}}{\Delta t_{\xi}}+\operatorname{div}_{h} \mathbf{U}^{k+1}=0,
\end{gathered}
$$

where

$$
\mathbf{U}=\int_{-H}^{0} \mathbf{u} d z
$$

Time step $\Delta t_{\xi}$ is limited by the stability criterion of the explicit numerical scheme. Equations (3) and (4) are solved from $k_{n}=n \Delta t_{u} / \Delta t_{\xi}$ to $k_{n+1}=(n+1) \Delta t_{u} / \Delta t_{\xi}$.

The forcing term

$$
\mathbf{F}^{n, n+1}=\boldsymbol{\tau}^{n}-\boldsymbol{\tau}_{b}^{n}+\int_{-H}^{0}\left(\mathbf{M}_{h}^{n}-\Lambda_{h}^{n+1}\right) \tilde{\mathbf{u}}^{n+1} d z
$$

derived from Eq. (1), is fixed from $n \Delta t_{u}$ to $(n+1) \Delta t_{u}$. The intermediate 3D current distributions $\widetilde{\mathbf{u}}^{n+1}$ are further corrected by subtracting the incorrect vertical mean

$$
\mathbf{u}^{n+1}=\tilde{\mathbf{u}}^{n+1}+\frac{\mathbf{U}^{k_{n+1}}}{H}-\frac{1}{H} \int_{-H}^{0} \tilde{\mathbf{u}}^{n+1} d z
$$

to ensure that divergence of $\mathbf{u}^{n+1}$ is consistent with the water level change.

For modelling of current pattern time series, the above 3D circulation model is implemented in a four-step nested way with the grid step ratio $4: 1$ between the subsequently nested coarser and finer grids. All the grids have different time step for 2D mode based on the computational stability criterion and equal time step for 
the 3D mode based on the period of dominating water level oscillations and response time of the nonstationary Ekman spiral. We use here one-way nesting with bilinear time-space interpolation of the water level at the open boundary of the finer grid, using the results from the coarser one. Being well aware of the increased computational noise at the finer grid open boundaries $\left[{ }^{15}\right]$ since smaller scale disturbances cannot propagate into the coarser grid, the noise was satisfactorily damped by introducing the boundary sponge layer where horizontal viscosity was artificially increased. By that, normal to the open boundary advective and viscous momentum fluxes were ignored. Test calculations revealed that in the geographical locations that are away from the coast at least for some grid points of the coarsest grid, both the water level and the currents agree well for all the four grids.

The coarsest grid of the model covers the whole Baltic Sea area with a grid step $8^{\prime}$ by longitude and $4^{\prime}$ by latitude. The bottom topography for the two of the coarsest grids has been generated from the IOW gridded depths $\left[{ }^{16}\right]$. By the grid refinement factor 4 , the finest grid reached the step of about $120 \mathrm{~m}\left(2 / 16^{\prime}\right.$ by longitude and $1 / 16^{\prime}$ by latitude). Topography of the two of the finer grids was interpolated with the Kriging (optimal interpolation) method from the raw depth mapping data from the Hydrographic Division of the Estonian National Maritime Board and from the recent geological investigations $\left[{ }^{17}\right]$. The coastline was taken from the 1:50000 digital base map provided by the Estonian Land Board. Bottom topography of the two of the finest model grids is shown in Fig. $1^{*}$.

\section{FORCING AND CALIBRATION OF THE CIRCULATION MODEL}

For calibration purposes, the circulation model was forced by actual local wind measurements recorded at Undva Cape $\left[{ }^{12}\right]$ with $5 \mathrm{~min}$ intervals at the height of $15 \mathrm{~m}$ above land and $20 \mathrm{~m}$ above sea level. Recorded data correlated well with the data from a standard meteorological station located at Vilsandi Island $15 \mathrm{~km}$ away to the south-west. Altogether 8 model calibration experiments were done. Wind stress parameterization was adopted from Lehmann $\left[{ }^{18}\right]$ who made corrections to the standard quadratic ocean wind stress scheme in order to better account for the Baltic Sea conditions. The modelled current time series during a 6 week period starting from 31 August 2000 were compared with observed currents recorded for the same period near the three possible harbour locations $\left[{ }^{12}\right]$.

First runs with constant horizontal and vertical viscosity coefficients gave too large current speeds during stronger winds while during weaker winds the current speeds more or less agreed. In the following experiments, Smagorinsky formulation of turbulent viscosity was introduced in the form

$$
\mu=\gamma L_{x} L_{y} \sqrt{\left(\frac{\partial u}{\partial x}\right)^{2}+\frac{1}{2}\left(\frac{\partial u}{\partial y}+\frac{\partial v}{\partial x}\right)^{2}+\left(\frac{\partial v}{\partial y}\right)^{2}},
$$


where $u$ and $v$ are horizontal current velocity components, $L_{x}, L_{y}$ are the turbulent motion length scales taken usually equal to the numerical model grid steps $\Delta x$ and $\Delta y$, and $\gamma$ is tunable Smagorinsky coefficient (final calibration gave $\gamma=0.25$ ). Vertical viscosity has been taken as a step function with different values in the upper and lower layers. Their variation within reasonable limits did not change considerably the results and introduction of a vertical turbulence model with variable coefficient was considered unimportant for the present study. Vertical viscosity used later was $25 \mathrm{~cm}^{2} / \mathrm{s}$ for the upper layer above $20 \mathrm{~m}$ depth (with a wind stress dependent increase, if the wind stress exceeded $1 \mathrm{dyn} / \mathrm{cm}^{2}$ ), and $1 \mathrm{~cm}^{2} / \mathrm{s}$ for the lower layer below $20 \mathrm{~m}$.

The next calibration problem arises with the wind stress distribution. Since the gridded wind field data were not available over the whole Baltic Sea for the study period, the wind measured at Undva Cape had to be applied over the entire Baltic Sea. During the calibration runs, however, the Undva wind was applied with a Gaussian spatial decay factor centered in the bays of interest. This enabled somewhat to suppress artificial generation of water level seiches that otherwise (spatially constant wind over the sea) became rather strong also in the signal of currents. At the same time, as is evident from the weather patterns, there might be strong winds in other areas of the Baltic Sea in which delayed water level signal can increase the currents in the bays of interest even if the local wind speeds are rather small. Such current strengthening events that are out of phase from local wind increase events are noted in $\left[{ }^{12}\right]$. They are also evident in Fig. 2 where both the modelled and observed current speeds and directions are presented for the buoy station location near Suuriku-Kuriku. The calibration for this location is satisfactory.

Another calibration problem arose from the coastal influence on the wind stress distribution over the bay. Measurements of the wind speed distribution over both bays showed remarkably smaller wind speed near the coasts as compared to the open sea winds. As presented in a personal communication by Timo Vihma (Finnish Institute of Marine Research), the lateral scale of the wind speed reduction near the coast has been estimated by meteorological station onboard r/v Aranda for several tens of kilometers. Since the coupled atmosphere-ocean model was out of the scope of the present study, we hit on a simple approach and assumed the local wind speed near the coast $\vec{V}_{10}$ to be dependent on the undisturbed wind speed $\vec{V}_{10}^{*}$ and on the fetch distances of the sea point to the coast in downwind $\left(F_{d}\right)$ and upwind $\left(F_{u}\right)$ directions. Christoph Lüpkes from the Alfred-Wegener Polar Research Institute, Bremerhaven, has told in a personal communication that typical downwind speed reduction distance from the coast is $30 h_{0} \quad\left(h_{0}\right.$ is the height of the coastal plateau). In the case of highest coast on the Tagamõisa Peninsula, $12-15 \mathrm{~m}$ near Suuriku-Kuriku, plus $15 \mathrm{~m}$ for the forest, we get the coastal influence up to $900 \mathrm{~m}$ towards sea. Direct wind measurements over the bays suggested no reduction of speed at a distance of $3 \mathrm{~km}$ from the coast and 
(a)

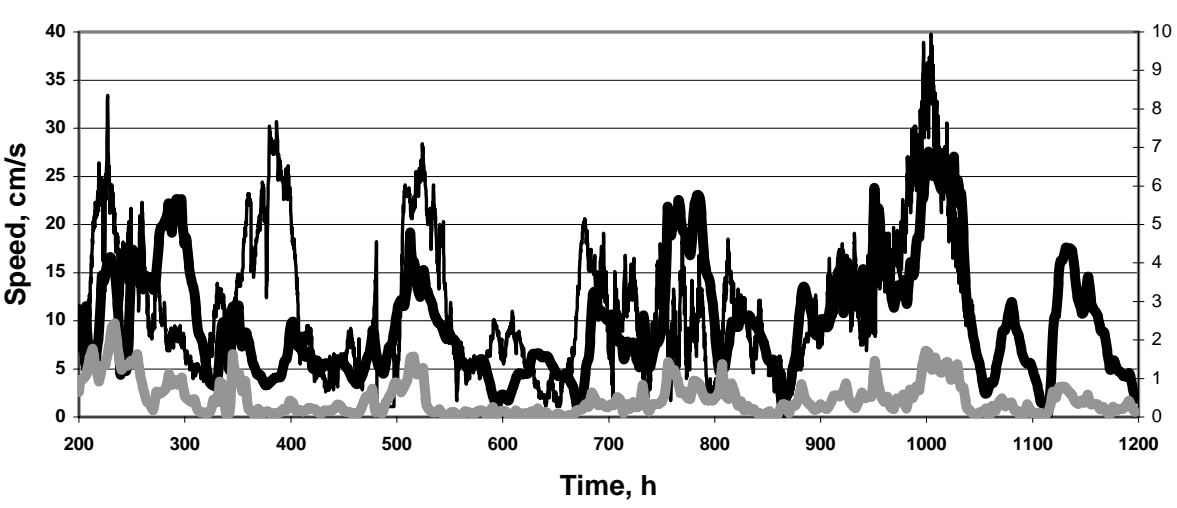

Modelled speed $\longrightarrow$ Observed speed $\longrightarrow$ Wind stress

(b)

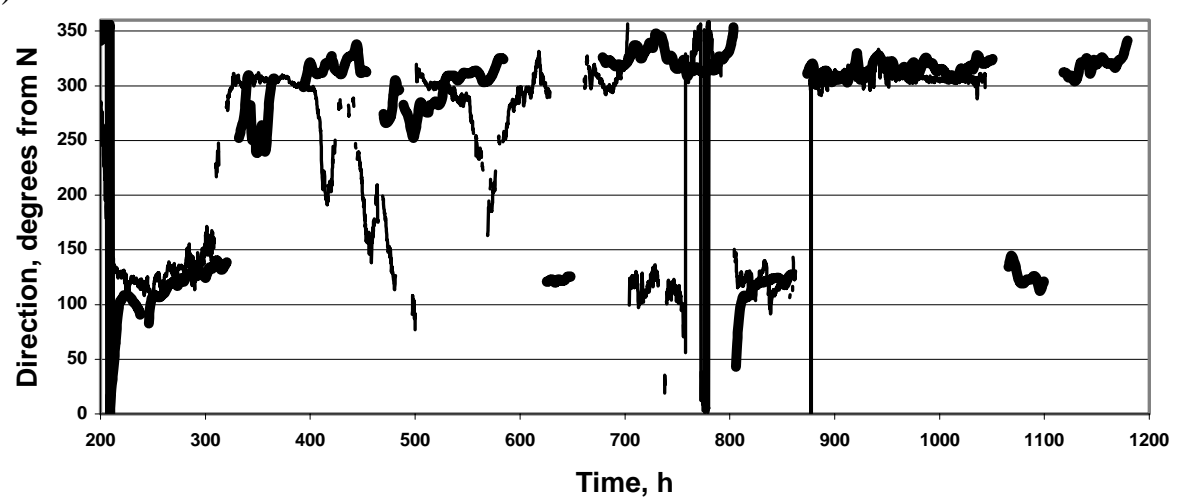

Direction of modelled current $\longrightarrow$ Direction of observed current

Fig. 2. Modelled and observed current speeds (a) and directions (b) near Suuriku-Kuriku. The lowest curve in (a) is the wind stress ( $\mathrm{dyn} / \mathrm{cm}^{2}$, right vertical scale) observed at Undva Cape. Hours are counted from 00:00, 31 August 2000.

reduction of wind speed by about $50 \%$ at $1 \mathrm{~km}$ from the coast. Without having available any reliable parameterization for wind speed reduction, we finally adopted the formula

$$
\vec{V}_{10}=\vec{V}_{10}^{*}\left(b_{d}+\left(1-b_{d}\right) \tanh \frac{F_{d}}{L_{d}}\right)\left(b_{u}+\left(1-b_{u}\right) \tanh \frac{F_{u}}{L_{u}}\right),
$$

where the downwind and upwind decay distances were taken as $L_{d}=1.5$ and $L_{u}=1 \mathrm{~km}$, respectively. The open sea wind speed fractions near the coast were taken as $b_{d}=0.1, \quad b_{u}=0.3$. Introduction of the wind reduction (Eq. (8)) 
improved first of all the match between the modelled and observed current directions at Suuriku-Kuriku. Furthermore, it was the only possibility within the given model to keep the modelled currents in the Uudepanga Bay much smaller than at Suuriku-Kuriku as came surprisingly out from the direct current measurements $\left[{ }^{12}\right]$. At Vaigu the current meter was unhappily deployed just in the deeper side of the underwater bottom step that generates local small-scale current variability what is outside the capability of the present model.

The locally calibrated circulation model was further run for a 32 week long period using the SMHI gridded wind fields over the Baltic Sea with a $3 \mathrm{~h}$ time step during $1991\left[{ }^{19}\right]$. This wind period was checked to represent the basic longterm statistics of wind speed and direction. Advantage of the use of gridded spatial wind distributions is the proper excitation of long water level waves and avoiding artificial amplification of seiches. The current distributions for the finest grid (Grid 4) were recorded with 20 min interval in order to make statistical estimates of currents and oil drift probability.

\section{CURRENT PATTERNS}

The instantaneous circulation in both of the bays is rather variable depending on the local wind forcing and remote forcing by long water level waves. The results from the model agree with the observed current schemes. In the Uudepanga Bay, the currents have generally one-layer structure that favours also circulation patterns for the surface currents. In the Tagalaht Bay the surface circulation is often distinguished from the compensation currents in the deeper layer, giving rise also to upwelling and downwelling.

Mean current vectors calculated for the 32 week period reflect the impact of dominating south-westerly winds $\left[{ }^{20}\right]$. Outside the Uudepanga Bay, near the capes of Harilaid and Undva, the currents are directed to the north-east. North from the Tagamõisa Peninsula the mean currents are directed to the east. In the Uudepanga Bay, the mean circulation is cyclonic where the open sea water enters along the western coast and leaves the bay along the eastern coast. In the Tagalaht Bay, the contribution of S and SE winds is remarkable in the mean circulation pattern. The currents are directed out of the bay along both the eastern and western coasts. The bay interior is governed by weak circulation cells. In the deeper layer of the Tagalaht Bay the inflow compensates the outflow in the upper layer.

For deriving the current patterns of specific wind directions, the wind time series as extracted from the gridded wind data were divided into four directional sectors: $0^{\circ}-90^{\circ}, 90^{\circ}-180^{\circ}, 180^{\circ}-270^{\circ}$, and $270^{\circ}-360^{\circ}$. From each sector, the wind speeds over $8 \mathrm{~m} / \mathrm{s}$ were sorted out and the corresponding instantaneous current distributions were further used in the averaging procedure. The resulting current patterns are given in Fig. 3. Within this procedure, also the different mean wind speeds in different sectors were taken into account. 
(a)

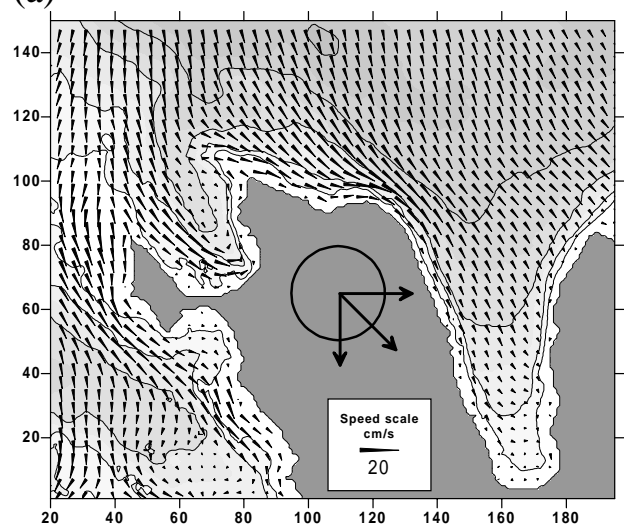

(c)

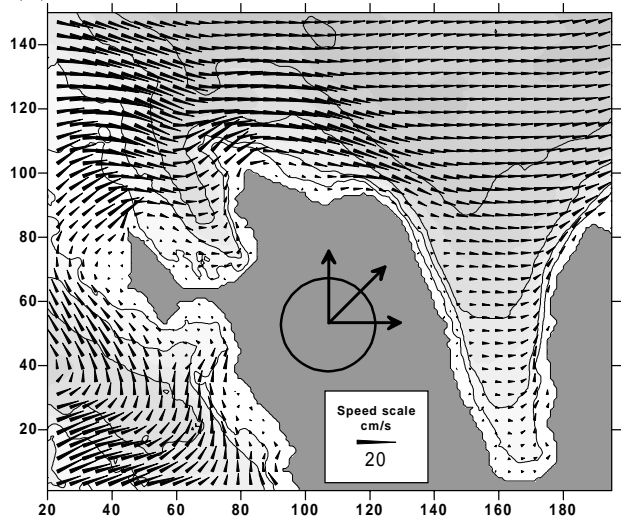

(b)

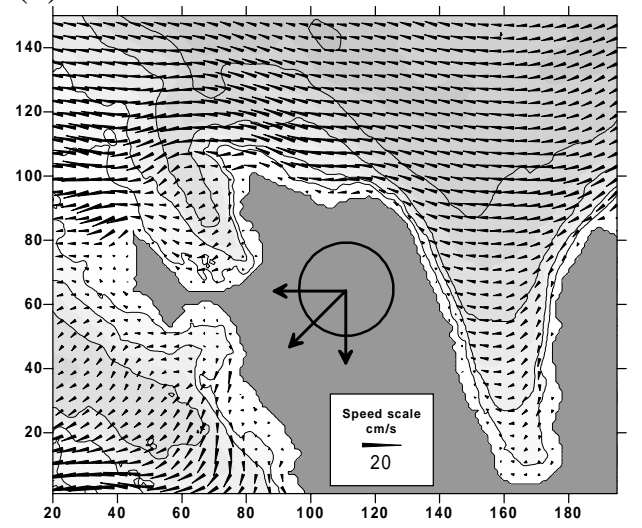

(d)

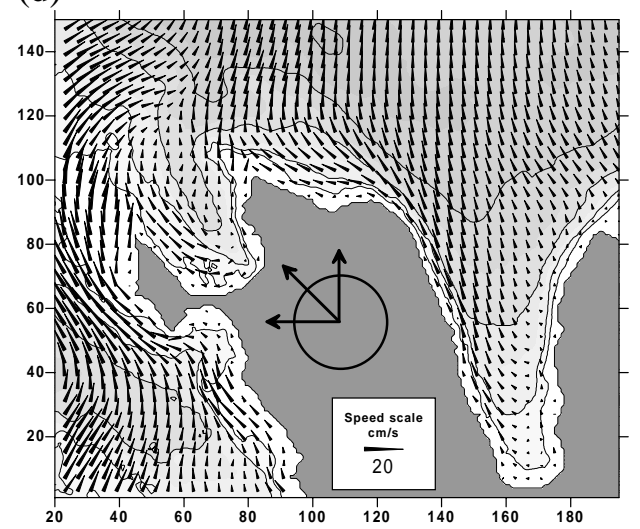

Fig. 3. Mean currents corresponding to the stronger winds (over $8 \mathrm{~m} / \mathrm{s}$ ) from different sectors: (a) wind directions $270^{\circ}-360^{\circ}$, (b) $0^{\circ}-90^{\circ}$, (c) $90^{\circ}-180^{\circ}$, (d) $180^{\circ}-270^{\circ}$. The numbers on the axes correspond to the grid points.

Mean currents corresponding to the SW winds are rather similar to the mean currents over the full modelling period. The main difference occurs in the Tagalaht Bay where the easterly current speed increases towards the eastern coast for SW winds, but as a long-term mean the outflow occurs in the upper layer. In the Uudepanga Bay, 75\% of wind directions favour northerly drift near the planned harbour site on the eastern coast and only NE winds force the southerly drift. According to paper $\left[{ }^{20}\right]$, stronger NE winds are rather seldom and thus most of the time the currents near the planned harbour site are not directed towards the Vilsandi National Park in the west but out of the bay along the eastern coast. 


\section{OIL SPILL SCENARIOS}

Estimation of oil drift probability is done by releasing the Lagrangian particles at different time moments of precomputed current patterns and recollecting final drift locations after $24 \mathrm{~h}$ of drift. The current pattern time series was 32 weeks long, recorded with 20 min intervals. The decimal geographical coordinates of the potential oil spill were taken as $X=22.0125, Y=58.5083$ for Suuriku-Kuriku, $X=22.0542, \quad Y=58.4698$ for Vaigu, and $X=21.9083$, $Y=58.4979$ for Undva. For a given spill location, 100 current-floating particles were released for drifting in the $120 \mathrm{~m}$ quadrant corresponding to the circulation model grid box. After drifting for $24 \mathrm{~h}$, based on the 72 precomputed current maps, the final coordinates were fixed and the grid-based counter summed the number of particles arriving to a specific grid box. The fragments of the $24 \mathrm{~h}$ drift were calculated within the whole time series of current maps. Altogether 16000 drift fragments were considered and the grid-based counter included information on trajectory endpoints of $1.6 \times 10^{6}$ drifters. The number of particles found in a specific grid box of the counter was further on transformed into the units of meteorological-type probability: number of days per year, when the elements of oil spill can be found in a quadrant with an area of 1 ha. Similar procedure has been applied by SMHI by a request of the organization WWF in order to estimate whether changing the Baltic Sea ship routes will reduce the probability of oil pollution in important seabird areas.

The results of oil drift probability calculations are shown in Fig. $4^{*}$. In the Uudepanga Bay, after $24 \mathrm{~h}$ of accidental oil release it is most probably found at $2 \mathrm{~km}$ to the north in the direction out of the bay, or a bit less probably at $1.5 \mathrm{~km}$ to the south. Small drift speeds favour localizing and removal of the spill. The most endangered coastal region is from the harbour site to the north until the Undva Cape. Probability of drifting the oil into the Vilsandi National Park, that lies about $2 \mathrm{~km}$ to the west from the considered harbour site, is rather small. In the case of oil spill near the planned Vaigu harbour, the area where oil can be most probably found, is the largest. This harbour location is considered as less suitable. Since during SW winds the surface currents may be directed offshore towards the eastern coast of the bay, then oil pollution may be found after $24 \mathrm{~h}$ in different coastal areas: alongshore at $4.5 \mathrm{~km}$ to the north, $4 \mathrm{~km}$ to the south or on the $4 \mathrm{~km}$ shore segment of the eastern coast of the Tagalaht Bay. Possible oil dispersion is smallest at Suuriku-Kuriku. During SW and SE winds the currents detach from the shore due to the coastline curvature and proceed correspondingly to the east and with a smaller speed to north-west. However, the structure of currents is relatively stable. After $24 \mathrm{~h}$ of an accidental oil release, it is most probably found at 2 to $4 \mathrm{~km}$ to the south along the coastline or at 2 to $4 \mathrm{~km}$ to the east towards open waters. With lower probability the pollution may be found at $2 \mathrm{~km}$ to the west along the coastline. The probability of pollution drift until the Undva Cape, known as Steller's Eider wintering area, is small for the SuurikuKuriku site but considerable for the Undva site. 
(a)

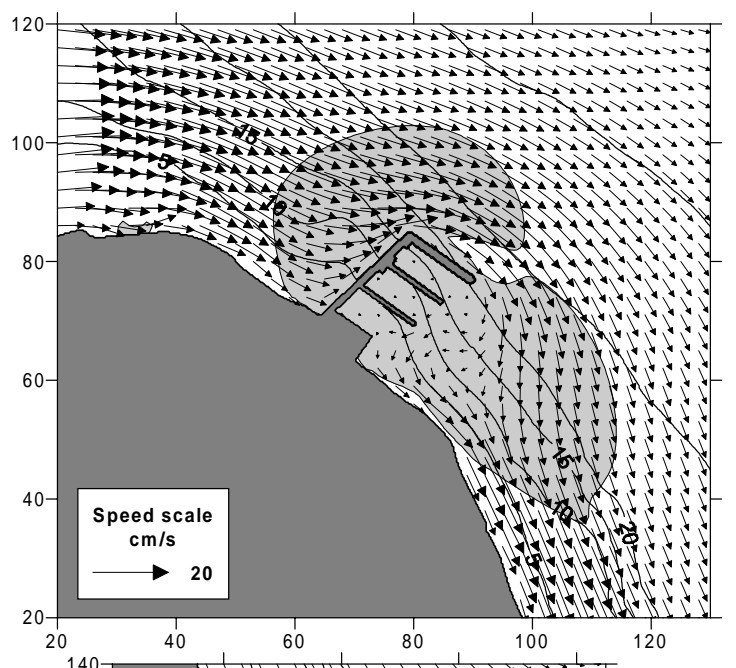

(b)

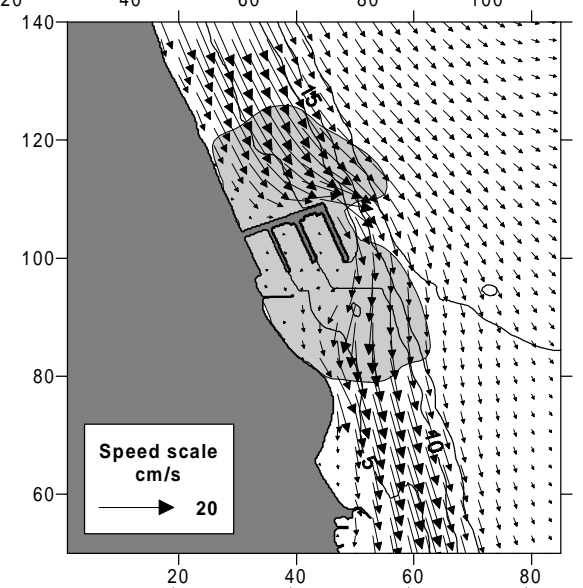

(c)

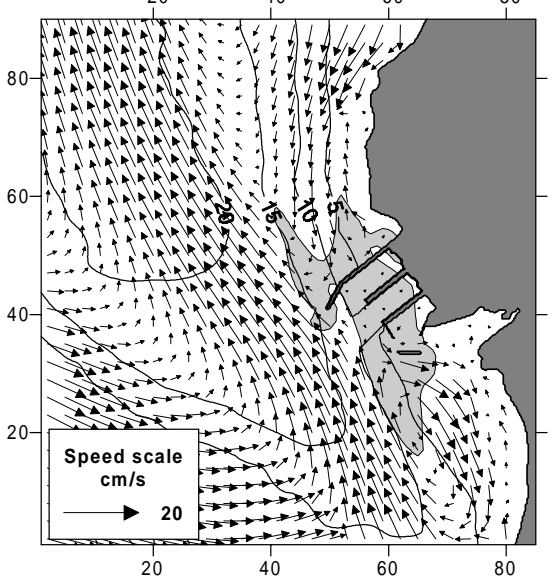

Fig. 5. Stationary depth-mean current patterns corresponding to the wind $15 \mathrm{~m} / \mathrm{s}$ of $330^{\circ}$ direction at Suuriku-Kuriku (a), Vaigu (b), and Undva (c). The shaded area indicates the region where the harbour installations change the currents more than $2 \mathrm{~cm} / \mathrm{s}$ as compared to the conditions before the harbour construction. The numbers on the axes correspond to the grid points. 


\section{INFLUENCE OF HARBOUR INSTALLATIONS ON LOCAL CIRCULATION}

One of the questions raised by the selection of the deep harbour site in Saaremaa is whether the harbour installations - breakwaters, piers, etc. - will modify the circulation and the water exchange efficiency in the bays and in the vicinity of harbours. Investigation of this problem was based on the harbour plans $\left[{ }^{21}\right]$. The circulation model grid was further refined to the $7.5 \mathrm{~m}$ grid step that allowed resolving even the harbour basins on the model grid. The calculations were done for the present conditions and for the case when the harbour construction is finished. It has been assumed that current patterns adjust to the wind more rapidly than the wind can change. The model for the local circulation was based on 2D non-linear shallow water equations with nesting the local computational grid into the coarser Grid4 generated earlier for bay-wide circulation. The model was time-stepped until reaching a stationary state corresponding to the given constant wind. Results from the grids with and without harbour installations were compared and rms difference of depth-mean current vectors were calculated. Examples of the results for all the three harbour sites with installations finished are given in Fig. 5.

For all the considered harbour sites, the influence of harbour installations to the circulation in the bays is small at Undva and practically absent at SuurikuKuriku and Vaigu. The impact of breakwaters and piers is limited to a region with about $1 \mathrm{~km}$ radius accounted from the shore as indicated in Fig. 5. This result was prior to calculations not obvious at least in the Uudepanga Bay where breakwaters of $300 \mathrm{~m}$ length close $10 \%$ of the bay cross-section.

In the immediate neighbourhood of harbours, the installations deflect alongshore currents and reduce the water transport on the lee side of installations. In the Uudepanga Bay, the band of compensation flow for depth-mean currents is very close to the seamost edge of the breakwater and the harbour installations cut the alongshore current on the eastern coast into two loops. On the seaward northern side, the detached coastal current merges with the compensation flow. To the south of the harbour, closed circulation is formed between the coastal wind-driven flow and the central compensation flow that may cause the effect of "dead" water in terms of ecology. Taking into account also other wind directions not shown in Fig. 5, the standing water may appear also at $1 \mathrm{~km}$ distance to the south from the planned Vaigu harbour. At Suuriku-Kuriku, stronger currents with alternating direction do not favour trapping of standing water.

\section{DISCUSSION AND CONCLUSIONS}

This study had to estimate the drift probability of oil spills potentially occurring near the considered harbour sites in the north-western Saaremaa Island. Since oil tankers are not envisaged to make a port call in the harbour, the 
accidental oil spill is most probably small. Due to the small size of the bays of interest, the time of oil movement before reaching the shore is about one day. The oil spill dynamics is mainly governed by advection that can be modelled by Lagrangian particle tracking based on modelled current patterns. Long term effects like evaporation, emulsification, entrainment, and subsurface transport are of smaller importance for short time scales and may be neglected in the model. Hindcast modelling of the Braer oil spill that occurred near the Shetlands in January 1993, revealed considerable simulation improvement if the hydrodynamic model used ten times finer grid $(924 \mathrm{~m})$ nested into the standard storm surge prediction model (grid step $5 \mathrm{mi}$ ) and more detailed wind forcing patterns were applied $\left[{ }^{22}\right]$.

In operational oil spill modelling, results of the trajectory analysis are critical by the formulation of operational response decisions $\left[{ }^{23}\right]$. The main uncertainty comes both from that of the meteorological forecast and of the hydrodynamical model in sparse data environment. In the oil drift probability calculations related to the environmental impact assessment, the hydrodynamic circulation model is used in the hindcast mode for calculating time series of current patterns that are long enough to encounter the long-term statistics of wind speed and direction. Within the present study, previous current measurement data were not available for the bays of interest. This circumstance did not allow to calibrate the model using wind field distributions available for the earlier period. The study had to compare the current data measured during the project with the results from the nested hydrodynamic model that was forced Baltic-wide by the local point measurements of wind. However, the agreement between the observed and modelled currents was satisfactory. Short deadlines of the study prescribe rather strong efficiency requirements for modelling. Present model therefore ignored baroclinicity because the measurements showed no detectable stratification in the bays of interest. It is expected that for other similar case studies the oil drift probability estimates would improve if better wind forcing will be available both on the Baltic-wide scale and the local scale, including proper parameterization of coastal effects on the wind field.

The oil drift probability study shows that among the three considered harbour locations in the north-western Saaremaa Island, the Suuriku-Kuriku site is most favourable. After $24 \mathrm{~h}$ of accidental oil release, it is most probably found at $2-4 \mathrm{~km}$ to the south along the coastline or $2-4 \mathrm{~km}$ to the east towards open waters. Less frequently, the pollution may be found at $2 \mathrm{~km}$ to the west along the coastline. The probability of pollution drift until the Steller's Eider wintering area, located at the Undva Cape, is very small. In the Uudepanga Bay the currents are unexpectedly weak. After $24 \mathrm{~h}$ of accidental oil release near Undva, it is most probably found at $2 \mathrm{~km}$ to the north, out of the bay, or a little bit less probably at $1.5 \mathrm{~km}$ to the south. Probability of the oil spill drift into the neighbourhood Vilsandi National Park is rather low. There is somewhat larger risk to Steller's Eider wintering area located about $3 \mathrm{~km}$ northwards from the harbour site. The current patterns are most unfavourable from the viewpoint of 
the oil drift at Vaigu. Since during south-westerly winds the surface currents may be directed offshore towards the eastern coast of the bay, then after $24 \mathrm{~h}$ of accidental oil release the pollution may be found with considerable probability on a large area over the bay: alongshore at $4.5 \mathrm{~km}$ to the north, at $4 \mathrm{~km}$ to the south or on the $4 \mathrm{~km}$ shore segment of the eastern coast of the Tagalaht Bay.

\section{ACKNOWLEDGEMENTS}

This study has been financed by the Estonian Ministry of Environment and partly (model development) also by the Estonian Science Foundation (grant No. 4171).

\section{REFERENCES}

1. Saaremaa süvasadama asukohavaliku keskkonnamõjude hindamine. Eesti Mereinstituut, Tallinn, 1999.

2. Seiser, P. E., Duffy, L. K., Mcguire, A. D., Roby, D. D., Golet, G. H., and Litzow, M. A. Comparison of Pigeon Guillemot, Cepphus columba, blood parameters from oiled and unoiled areas of Alaska eight years after the Exxon Valdez oil spill. Marine Pollution Bull., 2000, 40, 152-164.

3. Ben-David, M., Williams, T. M., and Ormseth, O. A. Effects of oiling on exercise physiology and diving behavior of river otters: A captive study. Can. J. Zool., 2000, 78, 1380-1390.

4. Kullapere, A. Wintering seabird counts at Vilsandi and vicinity areas in 1990. IWRB Western Palearctic Seaduck Database Newsletter, 1990, 1, 4-9.

5. Dick, S. and Soetje, K. C. An operational oil dispersion model for the German Bight. Dtsch. Hydrogr. Z., 1990, Ergaenzungsh. 16.

6. Mooers, C. N. K. South Florida oil spill research center. Spill Sci. Technol. Bull., 1997, 4, 3544.

7. Daniel, P. Operational forecasting of oil spill drift at Meteo-France. Spill Sci. Technol. Bull., 1996, 3, No. 1/2.

8. Elliot, A. J. and Jones, B. The need for operational forecasting during oil spill response. Marine Pollution Bull., 2000, 40, 110-121.

9. HELCOM. Recommendation 12/6 on development and use of oil drift forecasting. In Baltic Sea Environment Proc., 1991, No. 37.

10. Reed, M., Ekrol, N., Rye, H., and Turner, L. Oil spill contingency and response (OSCAR) analysis in support of environmental impact assessment offshore Namibia. Spill Sci. Technol. Bull., 1999, 5, 29-38.

11. Raudsepp, U. and Elken, J. Application of the Bryan-Cox-Type ocean model to reproduce synoptic and mesoscale variability of the Irbe Strait salinity front. Dtsch. Hydrogr. Z., 1999, 51, 477-488.

12. Kõuts, T. and Laanearu, J. Variability of currents in bays of Tagalaht and Uudepanga. Proc. Estonian Acad. Sci. Eng., 2001, 7, 126-140.

13. Klemas, V. Remote sensing of coastal fronts and their effects on oil dispersion. Int. J. Remote Sensing, 1980, 1, 11-28.

14. Killworth, P., Stainforth, D. D., Webbs, D. J., and Paterson, S. M. A free surface Bryan-CoxSemtner model. Inst. Oceanogr. Sci., Deacon Laboratory, Rep. No. 270, 1989.

15. Fox, A. D. and Maskell, S. J. A nested primitive equation model of the Iceland-Faeroe front. J. Geophys. Res. C., Oceans, 1996, 101, 18259-18278. 
16. Seifert, T. and Kayser, B. A high resolution spherical grid topography of the Baltic Sea. Meereswiss. Ber., 1995, 9, 72-88.

17. Kask, J., Perens, H., Perens, R., Suuroja, S., and Kask, A. Comparison of geological settings at possible deep harbour sites, north-western Saaremaa Island. Proc. Estonian Acad. Sci. Eng., 2001, 7, 99-125.

18. Lehmann, A. A three-dimensional baroclinic eddy-resolving model of the Baltic Sea. Tellus, 1995, 47A, 1013-1031.

19. Baltic Ecological Database. Weather. http://data.ecology.su.se/models/WeatherSMHI.html

20. Soomere, T. and Keevallik, S. Anisotropy of moderate and strong winds in the Baltic Proper. Proc. Estonian Acad. Sci. Eng., 2001, 7, 35-49.

21. Liiv, T. and Liiv, U. Saaremaa deep harbour layout design and computer simulation of the wave climate and sediment transport. Proc. Estonian Acad. Sci. Eng., 2001, 7, 174-192.

22. Proctor, R., Elliot, A. J., and Flather, R. A. Forecast and hindcast simulations of the Braer oil spill. Marine Pollution Bull., 1994, 28, 219-229.

23. Galt, J. A. Uncertainty analysis related to oil spill modeling. Spill Sci. Technol. Bull., 1997, 4, 231-238.

\title{
RANNIKUMERE TSIRKULATSIOONI JA ÕLIREOSTUSE LEVIKU MODELLEERIMINE SAAREMAA SÜVASADAMA VÕIMALIKES ASUKOHTADES
}

\author{
Jüri ELKEN
}

Saaremaa süvasadama asukoha valikul on vaja arvestada keskkonnamõjusid. Sellest seisukohast on uuritud õlireostuse leviku tõenäosust, kasutades tsirkulatsioonimudeliga määratud hoovustel triivivaid Lagrange'i osakesi. Neljaastmelise seotud arvutusvõrkudega tsirkulatsioonimudeli jämedaim võrk katab neljamiilise sammuga kogu Läänemere. Arvutusvõrkude ühesuunalise sidumisega vähendati igal järgneval võrgul ruumisammu neli korda, jõudes peenimal võrgul ruumisammuni 1/16 miili. Arvutusliku efektiivsuse huvides kohandati Bryani-CoxiKillworthi tsirkulatsioonimudelit ilmutamata arvutusskeemile ning barotroopsetele tingimustele. Kalibratsiooniarvutustel kasutati Undva ninas mõõdetud tuuleandmeid, mida ranna juures korrigeeriti tuule teekonnast sõltuva kahanemiskoefitsiendiga. Saadud tulemuste kokkulangevus otse mõõdetud hoovuskiirustega oli rahuldav. Kalibreeritud mudelit rakendati hoovuse mustrite 32 nädala pikkuse aegrea arvutamiseks. Järgnevalt arvutati õlireostuse leviku tõenäosus, määrates arvutusvõrgu loendurisse 24 tunni jooksul triivinud osakeste arvu. Kui süvasadam rajatakse Undvasse Vilsandi rahvuspargi lähedusse, siis rahvuspargi õliga reostumise tõenäosus on väike. Siiski jääb püsima Undva ninas paikneva kirjuhahkade talvituskoha reostumise oht. Sobivaim on Suuriku-Kuriku sadamakoht, kus õlireostuse leviku tagajärjed on kolmest vaadeldud sadamakohast kõige väiksemad. 